\title{
PENGARUH ADITIF EM4 (Effective Microorganism), AIR TEBU DAN TEPUNG JAGUNG TERHADAP KUALITAS UJI ORGANOLEPTIK SILASE RUMPUT KUMPAI (Hymenachine amplexicaulis)
}

\author{
(The Influence of EM4 (effective microorganism), Sugarcane Water and Corn flour on the \\ Quality Of organoleptic test Of Silage Kumpai Grass (Hymenachine amplexicaulis)
}

\author{
Kastalani, Maria Erviana Kusuma, Desty Laurena \\ Fakultas Peternakan Universitas Kristen Palangka Raya \\ Email: kastalani_46@ymail.com
}

Article Submitted : 23-4-2020

Article Accepted : 04-6-2020

\begin{abstract}
The study aims to determine the effect of various EM4 (effective microorganism) mixtures, sugarcane juices and corn flour on the physical quality of silage of Kumpai Grass (Hymenachine amplexicaulis). To get the right level of additive mixture to produce good dilation This research was conducted using a randomized complete design with treatment A (EM3 3\%, Sugarcane water $1 \%$, Corn flour 2\%), B (EM3 3\%, Sugarcane water 2\%, Corn flour 3\%), A (EM3 3\%, Sugarcane water 3\%, Corn flour 6\%), A (EM3 3\%, Sugarcane water 4\%, Corn flour 8\%). The observed variables were physical silage in the form of odor, texture and color. The result showed that the addition of EM4 (effective microorganism) additives, sugarcane juices and corn flour had no effect on organoleptic testing of silage Kumpai Grass (Hymenachine amplexicaulis).
\end{abstract}

Keyword : Silage, Kumpai grass, Corn flour, Sugarcane water, EM4

\section{PENDAHULUAN}

Ketersediaan pakan masih menjadi kendala pengembangan ternak ruminansia di Indonesia, di saat musim kemarau dimana ketersedian bahan pakan hijauan sangat kurang. Hal ini disebabkan sebagian besar bahan pakan bersifat musiman, terkosentrasi di suatu wilayah dan tepatnya manajemen pengolahan pakan yang diterapkan selama ini, sehinga pakan tidak bisa disimpan lama. Faktor lainnya adalah semakin sempitnya penanaman lahan hijauan pakan karena terjadi pengalihan fungsi menjadi kawasan permukiman dan industri.

Berbagai upaya yang dilakukan pihak pemerintah dengan selalu mencanangkan peningkatan jumlah ternak melalui berbagai program yang dilakukan melalui berbagai Instansi terkait, dalam rangka untuk meningkatkan populasi ternak sehingga dapat menyeimbangi jumlah konsumsi masyarakat.

Ternak sapi memberikan sumbangan daging yang besar terhadap konsumsi daging masyarakat. Saat ini pemerintah mengimpor sapi yang pada akhirnya diharapkan dapat menambah populasi ternak sapi dalam negeri.

Indonesia yang berada pada daerah tropis dengan pola iklim hujan dan kemarau, manakala musim penghujan sejumlah hijauan dapat tumbuh berproduksi secara maksimal, sedangkan manakala musim kemarau hijauan makanan ternak menjadi kekurangan. Keadaan ini jika tidak dilakukan antisipasi dengan melakukan berbagai upaya pengolahan dan pengawetan pakan, dapat menyebabkan keadaan ternak berubah. Pada musim penghujan ternak menjadi gemuk dan kurus pada musim kemarau. Keadaan ternak demikian dapat mengurangi produksi ternak. 
Menurut Mulyono (2004) bahwa pakan sangat penting diperlukan untuk pertumbuhan ternak karena mengandung zat gizi.

Kebutuhan hewan ternak ruminansia yang semakin tinggi, memaksa peternak harus inovatif dalam pemberian pakan hijauan pada ternak. Guna mengantisipasi jika musim kemarau datang dan pakan hijauan akan semakin sulit, maka peternak memerlukan cara penyimpanan bahan pakan segar atau bahan pakan simpanan dalam kurun waktu tertentu. Hal ini dapat dilakukan dengan pengawetan basah (silase) maupun pengawetan kering (hay). Sehingga kesulitan mencari bahan pakan saat musim kering

Penambahan EM4 ke dalam silase hijauan pakan ternak untuk tujuan penyimpanan hijauan pakan ternak segar akan menjadi lebih mudah dan lebih cepat. Selain itu penambahan EM4 akan meningkatkan nafsu makan ternak dari aroma asam manis yang ditimbulkan. Al-azhary (2006) sapi, kerbau dan kambing telah bisa diberikan silase larutan pada musim kemarau saat rumput juga sulit didapat. EM4 dapat digunakan sebagai probiotik pembuatan silase, rumput kering, jerami, pohon jagung kering dan lain-lain dapat diolah menjadi pakan ternak dengan dipotong kecil-kecil terlebih dahulu, potongan rumput kering ini ditaroh dalam bak drum atau tempat lain , disiram dengan EM4 sampai lembab dan dipadatkan.

Hariyatum (2017) Tebu merupakan salah satu tanmaan yang memiliki banyak manfaat, terutama pada bagian airnya. Selain bermanfaat sebagai pelepas dahaga, manfaat air tebu juga baik untuk kesehatan tubuh. Minuman ini memiliki rasa yang manis dan menyegarkan, karena di dalamnya terandung zat gizi seperti protein, glukosa dan karbohidrat. Karbohidrat yang terkandung dalam air tebu berfungsi sebagai bahan dengan pembentukan asam laktat pada proses ensilase yang sempurna (Bolsen, et al.1978). fungsi lain untuk mempercepat terbentuknya asam laktat serta menyediakan sumber energi yang cepat tersedia dalam bakteri (Sumarsih, et al.2009). berlangsungnya fermentasi asam laktat bahan pengawet biasanya ditambahkan untuk mencukupi karbohidrat mudah larut yang berguna dalam fermentasi, terutama dalam untuk menurunkan $\mathrm{Ph}$ silase (Matsuhima, 1979).

Menurut Suarni (2009), tepung jagung adalah tepung yang diperoleh dengan cara menggiling biji jagung yang bersih dan baik. Secara umum, terdapat dua metode pembuatan pembuatan tepung jagung yaitu metode basah dan metode kering, pada metode basah, biji jagung yang telah disosoh direndam dalam air selama 4 jam lalu dicuci, ditiriskan dan diproses menjadi tepung menggunkan mesin penepung. Sedangkan pada meode kering, biji jagung yang telah disosoh ditepungkan, artinya tanpa perendaman.Rumput kumpai (Hymenachine amplexicaulis ( Rudge) Ness) banyak tumbuh di rawa-rawa sekitar kota Palangka Raya, pemanfaatan sebagai pakan ternak ternak memang sudah banyak, namun untuk pemanfaatan sebagai pakan ternak melalui pengolah dengan silase dikalangan peternak masih sangat kurang.

Dari berbagai permasalahan diatas maka perlu dilakukan penelitian dengan judul : Pengaruh Campuaran Aditif EM4 (effective microorganism), Air Tebu Dan Tepung Jagung Terhadap Kualitas Uji Organoleptik Silase Rumput Kumpai Hymenachine amplexicaulis).

\section{METODE PENELITIAN}

Penelitian ini dilaksanakan selama 30 hari di Kebun Percobaan Fakultas Peternakan Universitas Kristen Palangka Raya Jalan RTA Milono Km 8,5 Palangka Raya. Materi yang digunakan pada penelitian ini adalah rumput kumpai, tepung jagung, EM4 dan air tebu. Adapun metode penelitian menggunakan Rancangan Acak Lengkap (RAL) dengan Perlakuan A= EM4 3\% + Air Tebu $1 \%+$ Tepung Jagung 2\%, B = EM4 3\% + Air Tebu 2\% + Tepung Jagung 4\%, C= 
EM4 3\% + Air Tebu 3\% + Tepung Jagung $6 \%$ dan perlakuan $\mathrm{D}=\mathrm{EM} 43 \%+$ Air Tebu $4 \%+$ Tepung Jagung $8 \%$. Masing-masing perlakuan diulang sebanyak 5 kali sehingga terdapat 20 satuan percobaan. Data yang diperoleh dilakukan uji statistik yaitu analisa sidik ragam untuk mengetahui pengaruh perlakuan. Jika hasil perhitungan menunjukkan perbedaan nyata atau sangat nyata maka akan dillanjutkan dengan Uji Duncan Multiple Range Test (DMRT).

\section{HASIL DAN PEMBAHASAN}

\section{Keadaan Umum Silase}

Dari hasil penelitian silase rumput kumpai secara umum menunjukan hasil yang baik. Warna hijau kecoklatan, bau sedikit asam namun tetap segar serta tidak busuk, tekstur padat dan agak lembek serta sedikit terkontaminasi dengan jamur. Peryataan tersebut sependapat dengan peryataan Harladi (2008) bahwa, secara umum silase yang baik mempunyai ciri-ciri yaitu warna masih hijau atau kecoklatan. Adapun tahap awal silase yang dibuat terasa silo-silo mengalami panas jika diraba. Hal ini menunjukan bahwa proses respirasi sedang berlangsung pada silase. Hal ini sesuai dengan pendapat Wallace and Chesson, (1995) di dalam Wisnu, (2009) proses utama yang terjadi dapat dibagi menjadi empat fase yaitu : 1) fase aerob, 2) fase fermentasi, 3) fase stabil; dan 4) fase anaerob mempunyai karakteristik tersendiri yang harus dikontrol untuk mempertahankan kualitas silase secara keseluruhan waktu panen, memasukan dalam silo, penyimpanan silo dan saat pemberian pakan pada ternak. Fase-fase tersebut diantaranya : 1) fase aerob, pada saat memasukan hijauan yang sudah dicacah ke dalam silo, ada dua aktivitas metabolis tanaman yang terjadi yakni respirasi dan proteolisis. Respirasi akan memecah gula dalam tanaman menjadi karbon dioksida (CO2) dan air menggunakan oksigen dan selama proses akan melepas panas. Sedangkan proteolisis akan memecah protein mejadi asam amino dan amonia; 2) fase fermentasi, dimana kondisi anaerob pada silo akan menyebabkan mikroorganisme anaerob mulai tumbuh. Bakteri asam laktat merupakan mikroflora yang sangat penting, karena akan menghasilkan asam laktat yang digunakan untuk mengawetkan hijauan.

Perubahan warna yang terjadi selama proses ensilase disebabkan oleh perubahanperubahan yang terjadi pada tanaman karena proses respirasi aerobik yang berlangsung selama persedian oksigen masih ada (Reksohadiprodjo, 1988).

Pada parameter Bau menurut Harladi (2008) bahwa, karakteristik silase yang baik adalah baunya segar agak berbau asam. Tekstur secara umum yang termasuk dalam golongan silase yang baik adalah tekstur silasenya padat, tidak berlendir dan tidak lembek (Siregar, 1998).

Adapun untuk meningkatkan kualitas silase rumput kumpai sebagai bahan pakan, maka faktor-faktor pembatas tersebut perlu diatasi. Salah satu pendekatan adalah dengan perlakuan fermentasi menggunakan EM-4. EM-4 merupakan produk campuran berbagai macam mikroba yang dibuat melalui inkubasi anaerob isi rumen dengan tambahan mineral dan bahan organik yang dibutuhkan mikroba (Haryanto et al.2005).

\section{Bau}

Hasil analisis ragam menunjukan bahwa penambahan aditif Tepung Jagung, EM4 dan Air Tebu tidak berpengaruh nyata terhadap kualitas fisik bau pada silase rumput kumpai. Rataan skor terdapat bau silase yang diperoleh dari hasil penelitian disajikan pada tabel 1. 
Tabel 1. Rata-Rata Skor Perlakuan Terhadap Uji Organoleptik Bau Silase Rumput Kumpai

\begin{tabular}{cc}
\hline Perlakuan & Rata-Rata \\
\hline A & 2,66 \\
B & 2,74 \\
C & 2,84 \\
D & 2,74 \\
\hline
\end{tabular}

Keterangan: Angka - angka yang diikuti huruf yang sama menunjukkan tidak berbeda nyata berdasarkan uji DMRT pada taraf 5\%.

Pada tabel terlihat pada antara perlakuan A (EM4 3\% + Air Tebu 1\% + Tepung Jagung 2\%), B (EM4 3\% + Air Tebu $2 \%+$ Tepung Jagung 4\% + EM4 3\%), C (EM4 3\% + Air Tebu 3\% + Tepung Jagung $6 \%$, ), D (EM4 3\% + Air Tebu 4\% + Tepung Jagung 8\%). Menunjukan tidak ada perbedaan terhadap bau silase rumput kumpai dengan skor (2,66-2,84) atau mendekati skor 3 asam (tetap segar). Dengan kata lain mendekati sempurna dengan skor tertinggi 3 yang menunjukan bahwa silase memiliki bau yang asam, hal ini sesuai dengan pendapat siregar (1996) yang menyatakan bahwa, secara umum silase yang baik mempunyai ciri-ciri rasa dan bau asam tetapi segar dan enak selanjutnya utomo (2013) menjelaskan bau silase secara umum asam. Hal ini disebabkan karena adanya produksi asam laktat selama proses fermentasi. Bau asam yang dihasilkan oleh silase disebabkan dalam proses pembuatan silase bakteri anaerob aktif bekerja menghasilkan asam organik.

Bau asam yang dihasilkan oleh silase disebabkan karena dalam proses pembuatan silase bakteri anaerob aktif bekerja dalam hal ini menghasilkan asam organik oleh karena itu asam dapat terbentuk. Wallace dan chesson (1995) menyatakan bahwa asam yang dihasilkan selama ensilase adalah asam laktat, propionate, formiat, suksinat dan butirat. Demikian pula pendapat Susetyo dkk., (1969) bahwa, dalam proses ensilase apabila oksigen telah habis dipakai, pernapasan akan berhenti, dan suasana akan menjadi anaerob. Dalam keadaan demikian jamur tidak dapat tumbuh dan hanya bakteri saja yang masih aktif terutama bakteri pembentuk asam. Dengan demikian, bau asam dapat dijadikan sebagai indikator untuk melihat keberhasilan proses ensilase harus dalam suasana asam.

Secara umum yang dimaksud dengan aditif dalam pembuatan silase adalah segala sesuatu yang dapat membantu ensilase yang berperan dalam mensuplai nutrien bagi bakteri asam laktat yang memproduksi asam laktat, enzim atau mikroba yang dapat meningkatkan ketersediaan karbohidrat atau nutien yang dibutuhkan bakteri pembentuk asam laktat. Penambahan aditif dalam pembuatan silase antara lain pertujuan : a) mempercepat pembentukan asam laktat dan asetat untuk mencegah fermentasi yang berlebihan, b) mempercepat penurunan $\mathrm{pH}$ sehingga mencegah terbentuknya produk fermentasi yang tidak diharapkan (butirat) dan c) memberikan suplemen nutrien yang efisien dalam hijauan yang digunakan.

\section{Tekstur}

Hasil analisi ragam menunjukan bahwa penambahan aditif Air Tebu, EM4 dan Tepung Jagung tidak berpengaruh nyata terhadap kualitas tekstur silase rumput kumpai.. Rata-rata skor terdapat tekstur silase yang diperoleh dari hasil penelitian disajikan pada tabel 2. 
Tabel 2. Rata-Rata Skor Perlakuan Terhadap Uji Organoleptik Tekstur Silase Rumput Kumpai

\begin{tabular}{ccc}
\hline Perlakuan & Rata-Rata \\
\hline A & 2,52 \\
B & 2,55 \\
C & 2,39 \\
D & 2,46 \\
\hline
\end{tabular}

Keterangan: Angka - angka yang diikuti huruf yang sama menunjukkan tidak berbeda nyata berdasarkan uji DMRT pada taraf 5\%.

Pada tabel 2 terlihat pada antara perlakuan A (EM4 3\% + Air Tebu 1\% + Tepung Jagung 2\%), B (EM4 3\% + Air Tebu $2 \%+$ Tepung Jagung 4\% + EM4 3\%), C (EM4 3\% + Air Tebu 3\% + Tepung Jagung $6 \%$, ), D (EM4 3\% + Air Tebu 4\% + Tepung Jagung 8\%). Menunjukan tidak ada perbedaan terhadap tekstur silase rumput kumpai dengan skor (2,39-2,55) atau mendekati skor 2 (agak lembek).

Dengan demikian perlakuan penggunaan aditif air tebu, tepung jagung dan EM4 tidak berpengaruh terhadap tekstur silase rumput kumpai. Hal ini menunjukan bahwa silase berada pada tingkat tekstur sedang sampai seperti hijauan segar. Silase ini dapat dikatakan baik karena tidak memiliki tekstur yang lembek, berair dan tidak menggumpal sesuai dengan pendapat
Kartadisastra (1997), bahwa silase yang berkualitas baik yaitu mempunyai tekstur segar, berwarna kehijau-hijauan, tidak berbau busuk, tidak menggumpal serta disukai ternak.

\section{Warna}

Rataan skor silase rumput kumpai dengan penambahan aditif air tebu, tepung jagung dan EM4 terhadap kualitas fisik silase rumput kumpai disajikan pada lampiran 4 . Sedangkan hasil analisis ragam disajikan pada lampiran 5. Hasil dari analisis ragam menunjukan bahwa penambahan aditif air tebu, tepung jagung dan EM4 tidak berpengaruh nyata terhadap kualitas warna silase rumput kumpai. Rataan skor terhadap warna silase yang diperoleh dari hasil penelitian disajikan pada tabel 3 .

Tabel 3. Rata-Rata Skor Perlakuan Terhadap Uji Organoleptik Warna Silase Rumput Kumpai

\begin{tabular}{ccc}
\hline Perlakuan & Rata-Rata \\
\hline A & 2,28 \\
B & 2,16 \\
C & 2,27 \\
D & 2,19 \\
\hline
\end{tabular}

Keterangan: Angka - angka yang diikuti huruf yang sama menunjukkan tidak berbeda nyata berdasarkan uji DMRT pada taraf 5\%.

Pada tabel 3 terlihat pada antar perlakuan A (EM4 3\% + Air Tebu 1\% + Tepung Jagung 2\%), B (EM4 3\% + Air Tebu $2 \%+$ Tepung Jagung 4\% + EM4 3\%), C (EM4 3\% + Air Tebu 3\% + Tepung Jagung $6 \%$, ), D (EM4 3\% + Air Tebu 4\% + Tepung Jagung 8\%). Menunjukan tidak ada perbedaan terhadap tekstur silase rumput kumpai dengan skor $(2,16-2,28)$. Atau mendekati skor 2 (hijau gelap atau kunimg kecoklatan).

Dengan demikian perlakuan penggunaan aditif air tebu, tepung jagung dan EM4 tidak berpengaruh terhadap warna silase rumput kumpai. Perubahan warna yang terjadi dikarenakan pada silase mengalami proses respirasi aerobik yang berlangsung selama persediaan oksigen 
masih ada, sampai gula yang terkandung dalam silase habis. Gula akan teroksidasi menjadi CO2 dan air, panas juga dihasilkan pada proses ini sehingga temperatur naik. Temperatur yang tinggi menyebabkan silase akan berwarna coklat tua sampai berwarna hitam. Hal ini sesuai dengan pendapat Prabowo et al. (2013), yang menyatakan bahwa temperature yang tinggi terkendali menyebabkan warna berubah menjadi coklat tua sampai kehitaman dan menyebabkan turunnya nilai pakan karena banyak sumber karbohidrat dan kecernaan protein turun. Hidayat (2014), menyatakan bahwa warna silase yang baik adalah coklat terang kekuningan dengan bau asam.

\section{KESIMPULAN}

Dari hasil penelitian dapat disimpulkan sebagai berikut :

1. Penambahan aditif EM4 (effective microorganism), air tebu dan tepung Jagung tidak berpengaruh terhadap kualitas uji organoleptik bau, warna dan tekstur silase rumput kumpai (hymenachine amplexicaulus)

2. Pengamatan secara organoleptik menunjukan penambahan aditif EM4 (effective microorganism), air tebu dan tepung jagung menghasilkan Bau asam namun tetap segar, Warna hijau gelap atau kuning kecoklatan dan Tekstur agak lembek.

\section{DAFTAR PUSTAKA}

Al-Azhary, K. 2016. Aplikasi Penggunaan EM4 Pada Peternakan-Teknologi Organik EM4. Http://KokolindsEm4.Blogspot.Com

Bolsen, K.K., Ashbell, G., Wilkinnson. 1978. Silage Additave In Biotechnology. In: Wallace, R.J, And Chesson (Eds). Animal Feeds And Animal Feeding. Weinheim: VCH.
Hariyatun. 2012. Pembuatan Silase. Htpp://Pendidikan PeternakanHariyatum.Blogspot.Com.

Haryanto, B., A., Thalib Dan S.N. Jerami, 2005. Peningkatan Nilai Hayati Jerami Padi Melalui Bio-Proses Fermentasi Dan Penambahan Zinc Organik. Pros Seminar Nasional Teknologi Peternakan Dan Vateriner. Bogor. 12-13 September 2005. Puslitbang Peternakan. Bogor. 473478.

Harladi. 2008. Sifat Dan Karakteristik Silase Rumput Gajah Mada Dengan Sumber Subtrat Yang Berbeda. Http://pakanruminansia.blongspot.com.

Kartadisastra, H. R. 1997. Penyediaan dan Pengelolaan Pakan Ternak Ruminansia (Sapi, Kerbau, Domba, Kambing). Kanisius, Yogyakarta.

Matsuhima, J, K. 1979. Feeding Beef Cattle. Spreger Verlag. Berlin Heidelberg. New York

Molyono. S. 2011. Teknik Pembibitan Kambing dan Domba. Penebar Swadaya. Jakarta.

Reksohadiprodjo, S. 1988. Pakan Ternak Gembala. BPFE. Yogyakarta.

Sumarsih, S., Sutrisno, C. I., Sulistiyanto, B. 2009. Kajian Penambahan Tetessebagai Aditif Kualitas Uji Organoleptik Nutrisi Silase Kulit Pisang. Seminar Nasional Kebangkitan Peternakan. Semarang.

Susetyo, S., I. Kismono., D. Soewardi. 1969. Hijauan Makanan Ternak. Direktorat Jendral Peternakan, Jakarta. 
Suarni. 2009. Perospek Pemanfaatan Tepung Jagung Untuk Kue Kering ( Cookies). Jurnal Penelitian Pengembangan Pertanian Vol.28, No 2Th. 2009.

Siregar, S. B., 1996. Ransum Ternak Ruminansia. Penebar Swadaya. Jakarta.
Wallace, R.J. and C. Chesson. 1995. Biotechnology in Animal Feeds and Animal Feeding. Winheim. Ithaca and London. 